\title{
HOLBERG OG DIE EUROPÄISCHE FAMA
}

\author{
EN KILDESTUDIE TIL HOLBERGS FøRSTE BøGER
}

$\mathrm{AF}$

\section{Sv. Eegholm-Pedersen}

$\mathrm{D}$

en første fase i Ludvig Holbergs lange forfatterskab omfatter tre bøger trykt $\mathrm{i}$ årene $\mathrm{I}$ 7 I-I 6 og udarbejdet eller bragt i endelig form medens han var alumne på Borchs Kollegium (I 709-I4). Det er-med et titelord der er lånt fra forbilledet Samuel Pufendorfs „Einleitung“ hans „Introductioner": Introduction til de fornemste Europæiske Rigers Historier (I III ), et derpå følgende Anhang i I 713 med skildring af samfundsforhold i Tyskland, England og Holland, samt Introduction til Naturens- og Folke-Rettens Kundskab (1716). ${ }^{1}$ ) Bøgerne er pionerarbejder - som senere holbergske værker indenfor andre genrer. Formålet var at skabe moderne populære håndbøger på modersmålet i nyttige og aktuelle videnskaber og forbilledet som næunt den tyske jurist og historiker Samuel Pufendorf ( $\left.163^{2-94}\right)$, der i 1672 havde udgivet sin store latinske håndbog i den nye naturretsvidenskab De Jure Naturæ et Gentium og i 1682 et historisk kompendium for studerende og unge statsembedsmænd: Einleitung zu der Historie der Vornehmsten Reiche und Staaten (...) in Europa (med et følgende bind $1686 \mathrm{og}$ fortsættelse efter Pufendorfs død, г 7o6).

Holbergs Europahistorie er væsentlig en annalistisk fyrste- og krigshistorie, gennemgående - men dog ikke hele vejen - ret uselvstændig og ukritisk i stoffets behandling og med begynderarbejdets ufuldkommenheder i plan og fremstilling - ufuldkommenheder som den unge forfatter selv undskylder i forordets captatio benevolentiæ: slutredaktionen måtte fremskyndes mere end helt godt var af frygt for en opdukkende konkurrent på markedet. Men bogen er den første egentlige Verdens- eller Europahistorie på dansk og som sådan et nyttigt og fortjenstfuldt arbejde. Den fik også efter Holbergs eget udsagn en gunstig modtagelse, og 
både Introductionen og Natur- og Folkeretten kunne komme i nye oplag, dog først i i 728; Naturretten blev senere optrykt endnu 3 gange i Holbergs levetid.

I nyere Holbergforskning har især det sidstnæunte værk - Holbergs Moralske Kierne som der også står på det oprindelige titelblad - påkaldt sig interesse. Kåre Foss leverede (1934) en indtrængende analyse af denne Pufendorfbearbejdelse, med et langt perspektiv i den europæiske filosofihistorie,$^{2}$ ) og i den sidste store Holbergudgave (Værker i Udvalg I-XII ved F.J. Billeskov Jansen. I969-7I) er den lille bog sat forrest som en nøgle til bærende tanker i forfatterskabet. Europahistorien og dens Anhang er behandlet af Th. A. Müller i en specialundersøgelse med en redegørelse for kildeforholdene. ${ }^{3}$ ) Det er også disse to bøger der er emnet for den følgende lille kildeundersøgelse, som føjer en brik til den mosaik der allerede er lagt af andre, nemlig foruden Th.A. Müller især Francis Bull og Sigurd Høst. ${ }^{4}$ )

Betydningen af det præcise kildestudium er demonstreret af Billeskov Jansen i grundlæggende litterære analyser. ${ }^{5}$ ) Også for undersøgelsen af de forskellige faser i Holbergs sprog og stil er det af stor interesse at kende og nøjagtigt bestemme forlæg og kilder. Holberg går ofte tæt på sine kilder i udnyttelsen af stoffet. Det gælder både de tidlige skrifter og de senere historiske og populære værker. Men i de første skrifter af den endnu ikke trænede skribent er kildeforhold og kildepåvirkning klart nok en særlig opmærksomhed værd.

Hvad var det da for bøger Holberg havde på arbejdsbordet da han gennemførte sit første store litterære projekt? Mange titler er næunt i fortaler og marginalnoter, nogle hovedkilder er benyttet stiltiende. Anhanget er, kan man nok sige, væsentlig en bearbejdelse af en 3-4 tyske, engelske, franske og latinske hovedkilder som anføres i fortalen, med tillæg om den nyere tid. Introductionen derimod bygger på et noget større håndbogs- og faglitterært apparat. I det ydre, format og typografi, er bogen en kopi af Pufendorfs Einleitung, en lille tyk oktav. Men også i udvalg og ordning af stoffet er der tydelig overensstemmelse, og afhængigheden viser sig rundt omkring tillige i fremstillingens enkeltheder, hvor Pufendorf benyttes på linie med andre stofkilder. Den vigtigste forskel er at Holberg udelader de afsnit der hos Pufendorf afrunder hvert lands historie med (ypperlige) oversigter over landenes indre forhold, geografi, befolkning, forhold til andre stater osv., det stof som efter planen skal behandles i Anhanget. Endvidere lægger Holberg i endnu højere grad end Pufendorf vægten på den nyere og nyeste historie. 
Foruden Pufendorf nævner Holberg i fortalen til Introductionen et andet universalhistorisk kompendium, nemlig Johann Hübner: Kurtze Fragen aus der Politischen Historia (I-X $1702 f f)$. Det er et værk af en helt anden karakter end Pufendorfs Einleitung. Det er anlagt som en skole- og lærebog efter den erotematiske metode, med spørgsmål og svar, resumerende oversigter og punktinddeling. Dette uhyre vidtløftige og i sammenligning med Pufendorf ukritiske værk har været en vigtig stofkilde for Holberg. Det er fx. benyttet i de første kapitler om Grækenland og Rom, her sammen med et andet - unæunt - historisk kompendium, Johs. Cluverus: Historiarum Totius Mundi Epitome ( $163 \mathrm{I}$ og mange følgende udgaver).

Iøvrigt anfører og anvender Holberg ved de fleste landes historie en række specialkilder, således meget fyldigt i Englandsafsnittet, og i kapitlerne om Danmark og Norge, der er helt selvstændige i forhold til Pufendorf, udnyttes de nationale historieskrivere, foruden latinsprogede kilder som Saxo, Krantz, Torfæus o.a. altså Snorre (i Peder Claussøns oversættelse 1633), Huitfeldt og Resen.

Holbergs hovedanliggende er den moderne historie. Fremstillingen af „disse sidste Tiders mærckværdige Historier", dvs. tiden efter I679 hvor Pufendorf slutter, indtager en uforholdsmæssig stor plads, bekender Holberg selv i fortalen, men det er jo det som interesserer læserne mest, „(jeg) haver (...) herudi rettet mig effter de fleestis gôu." Et tyngdepunkt i disse fyldige samtidshistoriske afsnit udgør den meget udførlige skildring af de europæiske krige i i 7oo-tallets første årti (den såkaldte Spanske Arvefølgekrig $\mathrm{I} 7 \mathrm{O} \mathrm{I} \mathrm{og}$ følgende år), som er samlet til sidst i det lange kapitel om Frankrig (Intr. I 448-515). Holberg anfører her ikke nogen kilder for sin fremstilling, og Th. A. Müller, der efterlyser en kildebestemmelse, formoder at forfatteren benytter aviser, gazetter eller et af tidens mange kompendier eller annaler. Det er åbenbart først $o g$ fremmest den sidste kildetype der leverer stoffet. Det kan nemlig vises at en hovedkilde til Holbergs skildring af den aktuelle europæiske krigshistorie - den spanske arvefølgekrig var ikke afsluttet da Introductionen udkom - er det store politisk-historiske månedsskrift DiE EuropäISche FAMA, som med trykkested i Leipzig var begyndt at udkomme i i $702 \mathrm{og}$ fortsatte (fra ${ }_{1} 735$ som Die neue Europäische Fama) til ${ }_{175} 6$.

Dette værk - med den fulde titel: Die Europäische Fama, welche den gegenwärtigen Zustand der vornehmsten Höfe entdecket - er et af de talrige skrifter som o. I $700 \mathrm{og}$ ind i I 700-tallet imødekommer det stadig stigende informationsbehov og - under navne som Zeitungs-Extract, Historischer und Politischer Mercurius, Secretarius, Relationes osv. - 

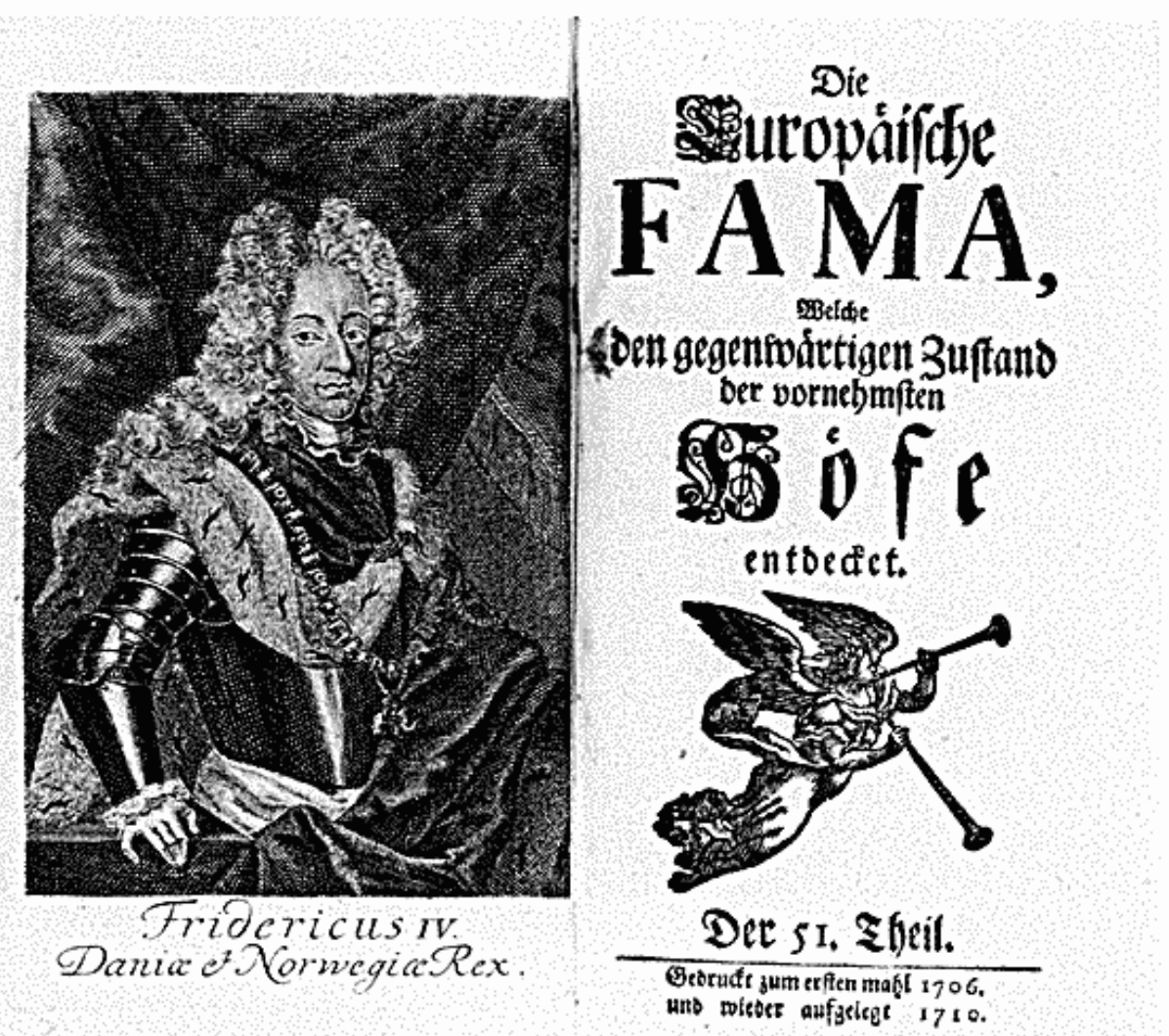

Frontispice og titelblad til Die Europäische Fama, 5 I. Theil (i 5 . årgangsbind, 1706 ) der bringer en udførlig omtale af de danske hjolpetroppers storartede indsats i Den spanske Arvefølgekrig, bl.a. i slaget ved Höchstädt (Hochstädt) og i Braband, jf. Holbergs Introduction I 7 I 4 .

forsyner det tyske avislæsende publikum med oversigter over og letlæst løbende orientering om begivenheder $\mathrm{i}$ ind- og udland. ${ }^{6}$ ) Det var med sine mere end 50 årgange det længstlevende og et af de mest udbredte af alle disse periodica. ${ }^{7}$ ) Der udsendtes årligt en I0-I 2 småhæfter på en 56 ark i oktav med fortløbende skildring af og kommentarer til begivenhederne $\mathrm{i}$ de forskellige stater og på krigsskuepladserne. Hvert hæfte er inddelt $\mathrm{i}$ afsnit der handler om de enkelte lande (Von Italien, Von Deutschland osv.) og er prydet med et stik af en fyrste eller en af de hærførere hvis bedrifter omtales $\mathrm{i}$ det pågældende nummer. Foran 2. Theil ( 1702 ) er $\mathrm{fx}$. et billede af den fra Collegium Politicum noksom bekendte prins Eugenius. Hæfterne indenfor hver årgang er meget prak- 
tisk forsynet med fortsat paginering og et afsluttende register (ved citering i det følgende henvises altså til årgang (romertal) og side).

Værket har klart populært sigte: aktuel information på grundlag af aviser og gazetter, meddelt $\mathrm{i}$ en levende og underholdende form. Det .hedder i den indledende korte programerklæring: „(...) mein Absehen seye, die merckwürdigsten Händel, so sich von Zeit zu Zeit an den vornehmsten Höfen begeben, auff eine belustigende Art zu erzehlen, und selbige jedesmahl mit einem unpassionirten Urtheil zu begleiten." Man kan nok diskutere hvor „unpassionirt“ forfatteren ${ }^{8}$ ) af de første årgange er; ved given lejlighed tager Fama patriotisk parti mod Frankrig, og især er der ofte en satirisk brod mod pavestolen som støtter Bourbonisterne. Den patriotiske tone træder stærkt frem flere steder, fx.i et afsnit hvor den østrigske hærfører prins Eugen (af Savojen) berømmes (IV 84): ,ich bin ein Deutscher, das ist, ein Landsmann desjenigen Volckes, welches zwar zu allen Künsten und Wissenschafften besondere Capacität, aber zu heuchlerischen Schmeicheleyen schlechte Inclination hat (osv.)“. Fremstillingen er altså personlig, subjektiv, med kontakt til læserne (V I6o: „die fleissigen Zeitungs-Leser") og med blik for stoffets underholdende kvaliteter, fx. i situationsbilleder som det følgende fra slagmarken: „(ihm) wurde (...) mit einer Stück-Kugel der Kopff hinweggenommen, und zwar an der Seite des Hertzogs de la Feuillade, welchem ein Theil des Gehirns in das Haar sprützete" (V 6ra). Den levende og billedrige stil krydres undertiden af litterære allusioner: „der Gesandte müsse (...) den Kopff voller Grillen aus der Helden-Geschichte des Don Quixote de la Mancha gelesen haben“ (IV I 73). Spanierne kaldes - med hentydning til Gryphius' bekendte komedie om den storpralende soldat (I664) - horribilicribifacii (III 29), den usurperende polske konge Stanislaus Leczinsky sammenlignes med Molières Mascarille (der optræder som herre) (III I 26) osv. ${ }^{9}$ )

Det er tydeligt denne kilde Holberg benytter i den sidste del af Frankrigskapitlet i Introductionen, hvor fremstillingen skifter karakter og fra en mere summarisk form breder sig ud i en detaljeret gennemgang af hvert enkelt års kampagne og krigsbegivenheder. Intr. I $457 \mathrm{er}$ den første sikre parallel, sml. Fama III i 2 ff. Den annalistiske beretning er hos Holberg som i hans forlæg opdelt geografisk efter de enkelte krigsskuepladser, og Holberg samler stoffet som er spredt over forskellige numre af Fama, men let at lokalisere ved hjælp af registrene. Til skildringen af krigen i Norditalien og Savoyen i 1705 (Intr. I $467 \mathrm{ff}$ ) benyttes således bl.a. Fama III $427 \mathrm{ff}, 705 \mathrm{f}, 723 \mathrm{f}, \mathrm{IV} 30,327 \mathrm{f}$, og på tilsvarende måde udnyttes de følgende årgangsbind af Fama (V og VI) til frem- 
stillingen af begivenhederne i 1706 og 1707 , fx. Intr. I $494 \mathrm{f}$ den Napolitanske Expedition, jf. Fama VI 400, 47 I, $547 \mathrm{f}$ osv. Kildeudnyttelsen er flere steder ganske tæt, med ordrette oversættelser af udvalgte afsnit; i andre tilfælde er der tale om friere referater af forlægget. Man kan følge den hurtige excerperingsteknik og ofte se hvordan der sættes ind med nye led i beretningen hvor der er linjebrud i kildeteksten. Nedenfor i tillægget er meddelt et par prøver på kildebenyttelsen. Jeg giver her et eksempel på at også forfatterkommentarer glider over i Holbergs tekst: $\left.:^{10}\right)$

Das Glücke des Krieges hat in Wahrheit recht artig changiret. Der Duc de Marlborough gedachte sein Pferd an des Feindes Zaum längst der Mosel anzubinden und muste nachmahls die gantze Gegend verlassen. Der Churfürst von Bayern meynte seine Victorien biss hinter Breda auszubreiten, wie er aber genau nachrechnete, so war die Rechnung ohne dem Wirt gemacht, und alle Hoffnung im Huy verlohren (Fama III 845 f).

Saaledis forandrede Krigens Lycke sig. Hertugen af Marleborough tænckte at binde sin Hest ved Fiendens Gierde langst ved Mosel-strømmen, Men udi en Hast maatte forlade den gandske Egn, for at beskytte det som hørde hans egne Principaler til: Chur-Forsten af Bayern tænckte ogsaa, at udbrede sine Victorier til Breda; Men hand giorde ogsaa sine Regninger uden Vert, hvilcket Udgangen lærte (Intr. I 474).

Die Europäische Fama er tillige udnyttet i et par af de andre kapitler i Introductionen, foruden i Anhang hvorom nedenfor, nemlig flere steder $\mathrm{i}$ beretningen om Karl XII's østeuropæiske felttog og begivenhederne $\mathrm{i}$ Polen (Intr. II 9 I ff, jf. Fama III i 25f, 277 f, $334 \mathrm{ff}$; Intr. II $96 \mathrm{ff}$, jf.Fama IV $126 \mathrm{ff}, 223 \mathrm{ff}, 246 \mathrm{ff}$ ) og til de sidste sider i Danmarkskapitlet (Intr. I 7 $13 \mathrm{ff}$, jf. Fama V $158 \mathrm{ff}$ ). Den patriotiske beretning om de danske hjælpetroppers glorværdige indsats i den europæiske krig, bl.a. i slaget ved Hochstädt og i Braband - navne som dukker op igen i komedierne - er udskrevet af Fama 5I. Theil, som vier Danmark en speciel og smigrende omtale (se ndf. i tillægget).

De tre statsbeskrivelser i Anhang, afsnittene om Tyskland, England og Holland, indeholder også en del helt aktuelt politisk-historisk stof. Ligesom i Introductionen skilter forfatteren i sin fortale med de samtids- 
historiske afsnit: „hartad den tredie Deel - dette er nu en overdrivelse (er) excerpered af itzige Seculi Historie“, og også her er til excerperingen i vidt omfang benyttet Die Europäische Fama. Således har skildringen af dr. Sacheverells kampagne mod whiggerne før regeringsforandringen i England I 7 Io (Anh. $222 \mathrm{ff}$ ) sit forlæg i Fama IX $318 \mathrm{ff}$, og kapitlet om unionen mellem England og Skotland (Anh. I94 ff) bygger på Fama V $295 \mathrm{fr}$. Holberg aftrykker selve unionstraktaten in extenso efter Fama VI $45 \mathrm{ff}$ og med tydelige mærker af det tyske forlæg i oversættelsen. I Tysklandsafsnittet har han et længere stykke om bandsætningen af to tyske kurfyrster med tilhørende actserklæring (Anh. 66ff) på grundlag af Fama V I I ff, I 12 ff.

Die Europäische Fama har åbenbart været en vigtig kilde for den unge Holberg til orientering i ,itzige Seculi Historie“. Dog naturligvis ikke den eneste. Holberg henter også sit stof andensteds. For årene 1708 og 1709 i Introductionens Frankrigsafsnit har han således haft en anden mere kortfattet og lettere overskuelig kilde ved hånden, nemlig de supplementer som Johann Hübner i årene $1709 \mathrm{ff}$ udgav til sine Historische Fragen med referater af foregånde års begivenheder. En sammenligning med Hübners Supplement viser at dette må være nærmeste kilde for afsnittet om I 708-felttogene i Frankrigskapitlet og ligeledes har været forlæg for dele af skildringen af Karl XII's felttog i I 709 (kapitlet om Sverige Intr. II rogff, jf. Hübner Suppl. II ${ }_{1} 5^{2} \mathrm{ff}$ ). Også i de afsnit hvor Holberg væsentlig bygger på Die Europäische Fama tyder lejlighedsvise uoverensstemmelser i detaljer på at der benyttes flere kilder, og til årene for I 704 er der et andet, ikke identificeret kildegrundlag, formentlig oversigtsværker eller periodica af lignende art som Fama.

Den eneste gang Holberg selv nævner Die Europäische Fama er langt senere, nemlig i Epistel nr. 262 (3. bind af Epistlerne, I 750). Han refererer her, i en opsats der er kritisk vendt mod pietisterne, til „et Skiemteskrift, som er indrykket i den Europæiske Fama“, hvor hans landsmænd får følgende skudsmål: „Die Dänen beten mehr, als Gott es befohlen hat"! Imidlertid er det ikke lykkedes at verificere denne henvisning, som altså kan bero på en fejlhuskning eller fejlcitering af en anden kilde.

Som det fremgår af de meddelte paralleltekster fra Die Europäische Fama bruger Holberg sine kilder ikke blot som stofkilder, men også i givet fald som forlæg hvis tekst i mere eller mindre bearbejdet form glider ind i fremstillingen, også uden nødvendig angivelse af kildeforholdet. Dette er jo ikke nogen ny iagttagelse. Holbergs energiske kildebenyttelse, hans - i sammenligning med senere tiders strengere praksis 
med hensyn til citering og citatangivelse - frie udnyttelse af det foreliggende materiale kan belyses med eksempler også fra de senere værker. I Dannemarks og Norges Beskrivelse (1 729) står skildringen af reformationen $\mathrm{fx}$. som en næsten ordret overført Huitfeldttekst - uden kildeangivelse. $\left.{ }^{11}\right)$ I Kirkehistorien fra 1738 ligger teksten mange steder ganske nær ved hovedkilden, C. Fleury: Histoire ecclesiastique I $\mathrm{ff}\left(4^{0}\right)$ I $722 \mathrm{ff}$, som der gives en generel henvisning til i fortalen. De populære Helte- og Heltindehistorier er efter Holbergs eget udsagn extracter af forhåndenværende historier og biografier, som i flere tilfælde, men langt fra altid anføres osv. ${ }^{12}$ ) Hvad de første skrifter angår, så har Anhang, som Th. A. Müller har vist, for store partiers vedkommende karakter af afskrift (oversættelse) af de kilder som nævnes i fortalen. I Europahistorien er det især $\mathrm{i}$ den nyere historie med den bredere reportage $\mathrm{i}$ de samtidshistoriske afsnit (krigsskildringerne) at vi finder en tilsvarende udnyttelse af bestemte kilder - altså især Die Europäische Fama - i længere passager. ${ }^{13}$ ) På grund af sprog-ligheden bliver der ofte tale om rene verbatimoversættelser: Nach Eroberung dieses Platzes gieng der Duc de Vendome auf Vercelli los $>$ Effter dens Erobring gick Duc de Vendome los paa Vercelli; rïckte (...) vor Ivrea > ryckte (...) for Ivrea; Nachdem man in diesen beyden Königreichen lange Zeit einander die Zähne gewiesen $>$ Effter at disse tvende Riger havde (...) lange viset hinanden Tander osv. Normalt er fremstillingen dog mere selvstændig, som bearbejdelse eller koncentrat af et givet kildestof, og den unge forfatter viser her sin evne til at uddrage essensen af et stort stof og meddele det i en klar og overskuelig form. Også i de mere selvstændigt udformede afsnit kan naturligvis forekomme lån og reminiscenser fra kilderne.

Men forbillede og kildegrundlag for Introductionen er altså $\mathrm{i}$ første række nyere tyske håndbøger og populære oversigtsværker, for oldtidshistorien kommer hertil et latinsk kompendium (Cluverus, se ovf.). Det har utvivlsomt - rent bortset fra de direkte lån - haft betydning for sprog og stil i Holbergs debutarbejde, og det kan da være rimeligt og den gunstige læser forhåbentlig ikke uvelkomment at vi runder kildeundersøgelsen af med nogle betragtninger over denne side af sagen.

Holberg følte sig sprogligt usikker og på gyngende grund ved begyndelsen af sin skribentbane. I en ofte citeret passus fra fortalen til Orthographiske Anmerkninger ( 1726) beklager han sig over den manglende modersmålsundervisning $\mathrm{i}$ barneårene - han gik $\mathrm{i}$ tysk skole de første år i Bergen - og taler om de uheldige følger af ungdomsårenes mange udenlandsrejser med deres fremmedsprogspraksis: 
hver gang jeg kom hiem, var jeg udi samme Tilstand som Jean de France, i det at mit Moders Maal vilde ikke synderlig flyde for mig; Thi man kand let glemme det som man aldrig har forstaaet tilgavns. Endelig, da jeg skulde skride til solide Ting og skrive Dansk, kunde jeg ikke hitte paa Ordene, viste ej heller at orthographere dem ret. Jeg skrev derfore ligesom Ordene udi en Hast kunde falde mig ind. Naar jeg for exempel ikke kunde hitte paa det Ord I agtage (sic) skrev jeg beobagte, naar et Zignet ikke vilde falde mig ind, skrev jeg Pitskaft (osv.).

Det er altså tyske ord der falder i pennen når de danske ikke vil melde sig, og paralleller til de anførte afstikkende germanismer findes rundt omkring i de første bøger - ved siden af de mere almindeligt brugte tyske låneord som angelegen, angenem, Anhang, erlange, de flygtige, forlore, gemeen, geheim, gelinge osv. Holberg bruger her fx. hyppigt et ord som itzig, jetzig (= nuværende), som kun forekommer sjældnere i de senere skrifter, og han kan enkelte gange komme til at blande tyske ord ind i det helt almindelige ordforråd: etlige for nogle (Intr. I 239), uneens for ueens (II I I3). Man kan finde ordformer som absondre (flere steder, ved siden af afsondre), Angriff, bekan(d)t, Forvantskafft, Hert(z)og, Miraclemacher, Sc(h)laver. Der kan i disse og lignende tilfælde være tale om direkte eller indirekte afsmitning fra de mange tyske kilder. Når Holberg endvidere så hyppigt i de første skrifter bruger foransat artikel i flertal ved folkenavne og visse andre personbetegnelser (de Cimbrer, de Rebeller), så spores vel også her en påvirkning fra hans tyske vademecum'er. Typen, som i alle tilfælde skyldes tysk indflydelse, er iøvrigt almindelig $\mathrm{i}$ ældre dansk, specielt i bibelsprog siden Christian III's Bibel ( 1550 ), og forekommer også senere hos Holberg, men med aftagende frekvens. I ordforrådet er fremdeles de mange romanske fremmedord, som fx. er meget iøjnefaldende i de nyere militærhistoriske afsnit i Introductionen, et fælles træk for Holberg og de tyske kildeværker.

Hvad selve stilen og fremstillingen angår har Holberg sikkert nok taget ved lære eller ladet sig inspirere af kildeforlæggene - som venteligt var. Der manglede jo hjemlige forbilleder, og han var henvist til fremmede mønstre. De her så flittigt benyttede tyske håndbøger og oversigtsværker er populære skrifter med et ganske bredt folkeligt eller - som Pufendorf og Hübner der især er beregnet for unge læsere - pædagogisk sigte, og der er i de to sidstnæunte som i Die Europäische Fama lagt vægt på en underholdende og levende form. Forfatterne bruger således $\mathrm{i}$ 
udstrakt grad billedlige eller konkretiserende udtryk, folkelige talemåder o.l. Nogle eksempler fra Die Europäische Fama: Dasjenige (...) worüber gantz Europa anjetzo Maul und Nase aufsperret (II 554), er würde noch viel länger auf dem Kopffe gekratzet, und in die Finger gebissen haben (III 93), Die Rechnung war ohne den Wirth gemacht, und die Haut schon taxiret worden, ehe man noch den Bähren gefangen (III I 70), Der Duc d'Anjou, welcher (...) dem ErtzHertzog Carln die Possess einer so fetten Erbschaft gleichsam vorm Maule weggenommen, gedachte in seinem ersten Feldzuge Portugal auf einen Bissen zu verschlingen (III 205), (er) muste mit langer Nasen abziehen (IV 185), der Fürst Ragoczy, dem das Maul schon lange nach diesem fetten Bissen gewässert (IV 336), ich weiss nicht, ob denen Anjouisten nicht das Hertz in die Bein-Kleider wird gefallen seyn, als sie (osv.) (VI 597). Tilsvarende udtryk og vendinger finder vi hos Hübner, som fortalen til den danske oversættelse ( 1746 ) roser for den „muntre og flydende“ stil, og hos Pufendorf: keinem von beyden konte man wegen Geldmangel den Daumen auf dem Auge halten, Der gute König kam aus dem Regen in die Trauffe (Hübner), Die Spanier machten über selbiges grosse Augen, Sonderlich giengen die Englischen Sachen in Guienne den Krebsgang (Pufendorf). Det vrimler med udtryk som unter die Arme greifen, auf die Beine helfen, einander in Haare geraten, in den Haaren liegen, über Hauffen gehen, über einen Kamm scheren osv.

Holbergs Introduction er på flere punkter præget af sproglig usikkerhed og er heller ikke stilistisk noget egalt værk. Den populære fremstillingsform er målet, men der er mange lærde reminiscenser og ufolkelige træk i sproget. Flere steder møder man fx. latinindslag i form af citater (med eller uden oversættelse) og latinske udtryk og vendinger $\mathrm{i}$ den danske kontekst. Således følgende, blandt en række andre eksempler i oldtidshistorien hvor forfatteren arbejder med latinske kilder: (han) blev holdet for een Gud under det Navn Stercutio, qvia stercorandi agri rationem invenit [(under det Navn S.) fordi han opfandt en måde at gøde marken på], (Intr. I 33), (han) blev kaldet Varius, Qvasi Varios habens Patres, [(han blev kaldet V.) det vil sige: som har flere forskellige fædre], ( $\left.\mathrm{I}_{1} 3^{8}\right)$. Kompendiets sammentrængte fremstilling kan også undertiden virke tør og remsende, med monoton brug af de samme udtryk, så man får indtryk af at Holbergs excerpter er gået temmelig uformidlet over i teksten. Men der er også steder, bl.a. især den mere udførligt behandlede nyere historie, der er mere præget af forfatterens engagement og interesse og hvor stilen bliver mere journalistisk levende.

Og der er hos Holberg stilbestræbelser der faldet helt $\mathrm{i}$ tråd med hvad vi har set hos de nævnte tyske populærskribenter. Han bruger som disse med forkærlighed konkrete, levendegørende udtryk i stedet for mere 
neutrale, og billedlige, folkelige talemåder af typen ligge, komme i Haar med, vare om en Hals, faae af Halsen, paa Halsen, reise Kammen $i$ Veiret, skiere over een Kam, gaae paa Klingen, gaae Krebsgang, tage Masquen af, giore kort Process med, blive fast udi Sadelen, fegte med Sporerne, smore sine Stovler osv. Mange af disse vendinger er fælles for dansk og tysk fraseologi og går altså igen $\mathrm{i}$ identisk form hos Holberg og hans kilder. Jeg citerer et par stilprøver fra Introductionen: (de tyske kejsere) lode sig smugt noye med TydskLand, ladende Paverne buldre i Italien, som de selv lystede (I 309), Riget hafde mange glubende Naboer om sig (I 22), (de) maatte packe sig af Landet igien (I I6o), (de krigende parter) tumlede sig lystig om med hin andre (I 50 I f), (Xerxes) hafde lige saadan Appetit paa Gracken-Land som hans Fader (I I3), (han) gav (...) baade Bispen og Prestekaldet en goddag (II 2 I), man (...) ventede (ikke) andet end den Allierte Armee skulle lobe sine Horn af for denne magtige Stad (I 503), de bleve med blodige Pander viste tilbage igien (I 683), De Portugiser spant eller (: heller) ingen Silcke dette Aar (I 50 I); (han) tog Paven og hans Cardinaler ved Vinge-Beenet ( $\left.\mathrm{I}_{3} \mathrm{I} 6\right)$. At fælde eller blive dræbt i kamp kan udtrykkes med spøgende omskrivninger: Theocritus blev sendt til sine Forfedre (I I 73), den ulyckelige Gibraltars Beleyring (...) sendte nogle Tusinde Spanier og Franske til Skiertz-Ild (I 465), (han) modtog 50000 Polackere saavel, at 10000 glemte at vende tilbage (II I38), (de) huggede ham til Fricassee (II ${ }_{153}$ ) osv. ${ }^{14}$ )

Holberg betænker sig ikke på at låne et godt udtryk eller billede $\mathrm{i}$ farten, men han bidrager også i høj grad selv med muntre og prægnante formuleringer. Sammenligningen med kilderne kan vise hvordan han inspireres af sit forlæg og finder nye udtryk i det anslåede stilleje: der Cardinal der schon eingepackt hatte (...) ziehet wiederum gelindere Säyten auf (Fama IV 134): Cardinalen som allerede hafde ladet smore sine Stovler (...) miste (...) sit Helte-moed, fattede andre Cardinalske, og geystlige Tancker (osv.) (Intr. II 98), Da hiellen sich nun die Herren Polacken recht Polnisch, das ist, sie sahen wo der Zimmermann das Loch gelassen, und rennten davon (Fama IV I 36 ): Da lode de Polacker see, at de vare ingen Podagrici, mens ligesaa raske paa Beenene, som udi forrige Batailler, og lode de Sachser staae udi Sticken (Intr. II $9^{8)}$.

De sidste prøver er eksempler på den spøgende eller ironiske tone som Holberg undertiden anvender overfor de skildrede personer og forhold. I de afsnit der behandler den nationale historie holder forfatteren sig strengt indenfor den obligate undersåtlige ærbødigheds grænser. Men fx. i skildringen af Xerxes' mislykkede kampagne i Grækenland gotter Holberg sig formelig over at det gik så galt som det gjorde for den mægtige perserkonge, og i omtalen af pavestolen eller romersk-katolske forhold i det hele taget anslås flere steder i den nyere historie en ironisk- 
distancerende tone - på samme måde som man finder det i Die Europäische Fama, hvis stærkt kritiske holdning overfor pavestolen er nævnt tidligere.

I sin smukke bog om Holberg som historiker (I9I3) omtaler Francis Bull afsluttende Holbergs historiske stil og kommer ind på nogle af de her behandlede træk, som også har gyldighed for de senere historiske værker: tendensen til at levendegøre stoffet ved konkrete eller billedlige udtryk eller dagligdags talemåder, og de elementer af satire og ironi der kan findes i Holbergs fremstilling. ${ }^{15}$ ) Stilen kan ses som en ligesom naturnødvendig afspejling af forfatterpersonligheden, med den komiske sans som en faculté dominante. Men en sådan stil har også sine forbilleder, og Bull drager paralleller til oplysningstidens historieskrivere. Man kan da her for det tidlige forfatterskab pege på de tyske skribenter som Holberg brugte som afsæt for sit første arbejde: det var her han hentede det meste af sit stof og hvor han først så hvordan en moderne historiefremstilling med et bredt populært sigte kunne skæres til. 


\section{NOTER}

(1) Med i rakken hører også den håndskrevne fremstilling af Christian IV's og Frederik III's historie som Holberg havde overrakt Frederik IV, og som han i I. levnedsbrev kalder Introductio ad Historiam Danicam prioris seculi (L. H.s tre Levnedsbreve ved A.Kragelund I 86). Den indgik sammen med det senere ferdiggjorte afsnit om Christian V i kapitlet om de oldenborgske konger i Dannemarks og Norges Beskrivelse 1729. - (2) Ludvig Holbergs Naturrett på idéhistorisk bakgruun. Oslo 1934. - (3) Holbergs to aldste historiske Arbejder, i: Historisk Tidsskrift Io. Rakke IV I ff. 1937. (4) Francis Bull: Ludvig Holberg som historiker. Kristiania 1913; Sigurd Høst: Om Holbergs historiske skrifter. Bergen 1913 . Den her foreliggende kildeundersøgelse er en udløber af arbejdet med Holberg-Ordbogen (Holberg Ordbog I-V. DSL København I $98 \mathrm{I}-88)$, som i mange år havde til huse i Det kgl. Bibliotek. Biblioteket stillede med stor velvilje hyldeplads og kontorrum til rådighed og gav med sine rige samlinger indenfor den aldre litteratur ideelle betingelser for redaktorernes javnlige sonderinger $\mathrm{i}$ det holbergske kildemateriale. - (5) Holberg som Epigrammatiker og Essayist I-II. I938-39. - (6) Se nærmere R. E. Prutz: Geschichte des deutschen Journalismus. Hannover 1845 . s. 372 ff samt Joachim Kirchner: Die Grundlagen des deutschen Zeitschriftenwesens I-II. Leipzig 1928-31 (med udførlig bibliografi). - (7) Rakken blev fortsat yderligere et par år med Die neueste Europäische Fama St. $1-76$. Gotha $1760-65$ (Kirchner, bibliografi nr. 967). - (8) Den forste udgiver - if. Jöcher: Allgemeines Gelehrten-Lexicon IV (1751) 374: indtil 1710 - var ostrigeren Phil. Balth. Sinold von Schütz (1657-1 742), en meget produktiv litterat, bidragyder bl.a. til Europäischer Herold og oversatter af Grotius' De jure belli et pacis. - (9) I beretningen om kong Stanislaus citeres også historien om bonden Menalcas i Jacob Bidermanns Utopia som Holberg dramatiserede i Jeppe paa Bjerget (Fama III 54). - (10) Antikva i fraktursatsen sattes som kursiv her og i de ndf. og i tillagget meddelte større tekstprøver. - (11) Dannemarks og Norges Beskrivelse r roff, jfr. Danmarckis Rigis Krønicke ved Arild Huitfeld I-II. 1652-55. s. ${ }_{1} 304$ f, 132 I f osv. - (12) Se for Heltindehistoriene G. Rodes udgave 186r. - (13) En aktuel dansk reportage (i Peder Witt: Guds Vognborg om Dend Kongelig Majestæts Danske Flode (osv.). 1700 s. $9 \mathrm{fl}$ ) om den forenede svenske, hollandske og engelske flådes angreb på København sommeren 1700 indgår ordret $\mathrm{i}$ Holbergs tekst i Danmarkskapitlet (Intr. I 705ff). Nogle prøver på kildeudnyttelsen i den aldre historie (Peder Claussøns Snorre, Huitfeldt, Pufendorf) er meddelt af Th. A. Müller anf. skr. s. 25 ff. - (14) Se også Karl Mortensen i Acta Philologica Scandinavica XIV $56 \mathrm{ff}$ - (15) Dette er i de senere historiske varker dog mindre fremtradende end her i Introductionen. Spogefulde indslag findes også i Danmarkshistorien (se fx. Samlede Skrifter ved Carl S. Petersen VI 146, 175 , VII 279), og Holbergs larde kollega Hans Gram rynker lidt på næsen (Holberg Aarbog I924, 139), men de prager ikke fremstillingen på samme måde. 


\section{TILLÆG}

\section{Prøver på udnyttelsen af Die Europäische Fama i Introduction og Anhang.}

\section{Fama III ${ }_{427}$ f:}

Franckreich hatte (...) endlich den Entschluss gefast, Sr. Königl. Hoheit das Messer an die Kehle zu setzen, ich meyne, die Residentz-Stadt Turin zu überwältingen, und sie dadurch von Land und Leuten zu verjagen (...) Verua lieget (...) I6 welsche Meilen von Turin, und wird selbst durch das Fort Guerbignan bedecket. Man hat diesen Platz schon vorlängst vor eine considerable Festung gehalten, und findet man in den Jahrbüchern auffgezeichnet, dass, als ein gewisser Marchese von Montferat sie ehemahls belägert, die Bürger über der Pforte des Castells ein Schwein mit offenem Maule, als ob es eine über sich hangende Traube einschlucken wolte, nebst folgenden Italiänischen Reimen einhauen lassen:

Quando questo Porco pigliara l'Uva,

Il Marchese de Montferato pigliara Verua, Wenn diss Schwein die Traube wird in den offnen Rachen kriegen,

Als denn soll der Marggraff erst unser Verua besiegen.

(s. 705:)

Verua is derjenige Platz, dessen wir so offters gedacht, und welcher dem Duc de Vendome mehr Mühe, Zeit und Volck gekostet, als wenn er eine blutige Bataille verlohren.

\section{Intr. I ${ }_{4} 67 \mathrm{f}$ :}

Hertugen af Vendôme (...) ryckte (...) siden for den sterke Festning Verua, effter hvis Erobring, hand agtede at sætte hans Kongl. Høyhed Kniven udi Struben, jeg meener, bemægtige sig hans Residentsstad Turin, og forvise ham sit eget land. Bemelte Verua ligger omtrent 4 Tydske Mile fra Turin, hvilken den styrcker og bedekker meget. Den haver udi lang Tid varet holdet for en mægtig og vigtig Festning, og mand finder antegnet, at, da en Marqvis af Montferat havde engang beleyret den, havde Borgerne ladet afhugge paa Porten af Castellet et Svin med aaben Mund, ligesom hand ville opsluge en Drue der hang over ham, tillige med disse Italienske Vers:

Qvando questo porco pigliarà l'uva Il Marchese di Montferato pigliara Verua: Naar Svined med sin Mund kand denne Drue naa

Skal Verua strax for Marqvisen aaben staa.

Denne Festning kostede de Franske meere Folck end alle de andre Stæder, som de havde erobret tilforn, ja, den giorde større Skade paa den Vendomiske Armee end en stor Batailles Forliis. 


\section{Bon Dadunemard.}

159

fenn wuirben, bafertue ber Rảnferlide Şof tert

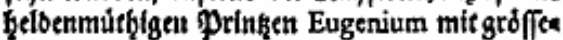
rem গadorud fecumbiret bydtte. Wie nun tit

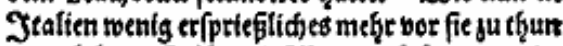

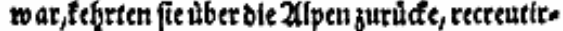
ten thre gefdinddite Eompagnien in Deutfd). lamb, unb marfditrten Anno 1705. unter Dem S5e. neral Harboë nad S) ungarn, wo feltbft fie unter bem Eommanbo des allba commantirender Rdy ferl. Senerals Comte de Herbeville etlidje mafil mit Den rebellen jum fandogemenge gea rathen, uno beg oer jüngften בattion in Sicbere birgen iffre Bravoure rebltá) gewote $[\mathrm{en}$.

Ditemigen Ddnifden Zrouppen, fo in Dent

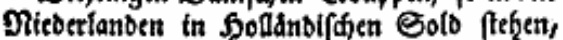

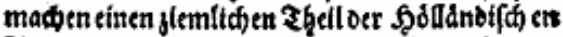
Zrmee aus, und twerben von S. Dut. Durd. Ocm fjerz̧og Carl, von 2 Búrtenberg comnantoiret. Ete marfdjitten Anno 1704. unter demfetbigent

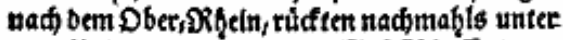
bem Prinşen Eugenio, in Befeufdaff beter Preuffen nad Sodrwaben, und ftunben ineift auf Dem red)ten fflúgel ber Zrmee, als Das ftharffe Zeffen ben J̧ddiftdot bor fid grenge, in weldem fie Das Jhrige reolth thaten, und getwiés nidje twentg juterlangten $\mathfrak{B}$ ictorie contribuirter. 习erwidenes Jaf̧r hqaben fie bey Eroberung ber Brabantifdeen Sinien fid befunben; Geuer aber

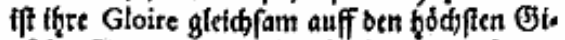
pfel geftiegen, inbem thre Snfanteric auf bem rectren flligel unter dem Duc de Marlborough, ble Eavallerie aber auf bem linden flüget unter

(L) $4 \quad \mathrm{bem}$

Fama V I59f:

Diejenigen Dänischen Trouppen, so in den Niederlanden in Holländischen Sold stehen, machen einen ziemlichen Theil der Holländischen Armee aus, und werden von Sr. Durchl. dem Hertzog Carl von Würtenberg commandiret. Sie marschirten Anno 1704, unter demselbigen nach dem Ober-Rhein, rückten nachmahls unter dem Printzen Eugenio, in Gesellschafft derer Preussen nach Schwaben, und stunden meist auf dem rechten Flügel der Armee, als das scharffe Treffen bey Höchstädt vor sich gienge, in welchem sie das Ihrige redlich thaten, und gewiss nicht wenig zur erlangten Victorie contribuirten. Verwi-
$7_{14}$

Dm Danntmaxd.

Den Senfertige Generals Comte d Herbevil ks Commande haver ladet fec Deris fore Tappetbed mod oe Malcontenter, beign oerlig uOi Den Aflios uDi Giebenburgen.

De Danfle ₹ropper/ fom faat uns Dee Sans Surdy. SDettugens' af $28 \%$ tenberg Commando uoi $\Re$ etocrianbene 1 gior en frop. Deel afoen Sootlanofte Armk. De marcbirede Anno 1704 under famme Gen:ral, til Dbetsolbinen, rutxe fioen urte Der Yyrink Eugenio til Suaben I og frobe melt paa ocn beyre fley. Slagblev boloet ved Sodis Stact bost udi of fiftede jum fover / og contribuerede veo Deris Tappetbeo ide libet tilfamme Viglorie. Uoi bet शlat 1705 fignaliferede oe fig ide minote ubi ben Szabandle finies crobring.

Rene Anno 1706 fige beris Reputse rion ligerom paa ben bonefie fpider i Det Deris Infanteric pao ten boyre Flon uns bee bertugen af Marlborougs, mens Caval. leriet paa oen venftec unber Felt-Marcball Outerkerk veb Derif inromparable Kappets bed $/$ gootmed of fietede mod de franfle Siongel.

Intr. 1714 :

De Danske Tropper, som staar under Hans Durchl. Hertugens af Wyrtenberg Commando udi Nederlandene, giør en stor Deel af den Hollandske Armée. De marcherede Anno 1704 under samme General, til Ober-Rhinen, rykte siden under Printz Eugenio til Svaben, og stode mest paa den høyre Fløy, da det store Slag blev holdet ved Hoch-Stædt, hvorudi de fiktede som Løver, og contribuerede ved deris Tapperhed icke lidet til samme Victorie. Udi det Aar 1705 signaliserede de sig icke mindre udi den Brabandske Linies erobring.

Mens Anno 1706 steg deris Reputation ligesom paa den høyeste spidse, $\mathrm{i}$ det 
chenes Jahr haben sie bey Eroberung der Brabantischen Linien sich befunden; heuer aber ist ihre Gloire gleichsam auff den höchsten Gipfel gestiegen, indem ihre Infanterie auf dem rechten Flügel unter dem Duc de Marlborough, die Cavallerie aber auf dem lincken Flügel unter dem Herrn Feld-Marschall von Ouwerkerk gestanden, und durch ihre unvergleichliche Tapfferkeit, mit welcher sie gegen das Königliche Französiche Hauss gefochten, den Sieg bey Judoigne, der sich schon sehr decliniret, bestätigen helffen (efter et indskud om det danske kavalleris tapre indsats mod de franske elitetropper sluttes:) welches eben die rechte Ouverture zu dem herrlichen Sieg gegeben.

\section{Fama V 296:}

Diese Herren kamen den 26. Aprilis zum erstenmahl in dem Pallast zu White-Hall zusammen, bey welcher Session der Lord Siegel-Bewahrer von Engelland durch einen pathetischen Discours die Eröffnung ihrer Commission gethan, und die Schotten versichert, „welchergestalt die Englische Nation (...) die Vereinigung beyder Reiche aufrichtig wünscheten, und ihres Ortes alles ersinnliche pouvoir zum Schluss dieses grossen Werckes beytragen würden. Nachmals hielte sich derselbe in seiner Rede bey den nützlichen Folgerungen auf, so hieraus zu erwarten stünden, und vergass darbey nicht zu remonstriren, wie das etablissement der Succession auf die Protestantische Linie absolut zur Ruhe und Sicherheit der Nation vonnöthen sey. Der Schottische Cantzlar antwortete in einer netten Rede, dass die Schotten nicht weniger hierzu geneigt wären, als die Engelländer, und dass er, nebst seinen Mitverwandten, alle mögliche Attention bey sich führe, diejenige Vereinigung zu facilitiren, von welcher das gemeinschafftliche Glück beyder Nationen dependire. deris Infanterie paa den høyre Fløy under Hertugen af Marlborougs, mens Cavalleriet paa den venstre under Felt-Marchall Ouverkerk ved deris incomparable Tapperhed, hvormed de fiktede mod de Franske Kongel. Huus Tropper og særlig imod deris Gens d'Armes restituerede den Allierede Arméee, da den allerede laa paa $\mathrm{Kn}$, og reve de Franske Seyeren af Hrnderne (Holberg benytter her noget stof fra Fama V $166_{3}$ og slutter:) og derved giorde en Ouverture til den herligste Seyr.

\section{Anhang r94f:}

Disse Herrer komme den 26. A pril forste gang sammen paa Palatzed til Withhal, og begynte da først Lord Seyl-Forvarer af Engeland udi en Oration at forsikkre Skotterne, at den Engelske Nation oprigtig ynskede begge Rigers Foreening, og vilde anvende all muelig Flid at bringe samme Verk til Fuldkommenhed, rorte siden om den Nytte og Fordeel, som der af vilde komme og forgiettede ikke at forestille hvor nødvandig Successionen paa den Protestanske Linie var for Nationens Fred og Sikkerhed. Der paa svarede den Skotske Cantzler udi en net Tale, at de Skotter vare ikke mindre der til genejede end de Engelske, og at han vilde anvende $\sin$ yderste Flid paa saadan Foreening, hvor af begge Nationers Velfert henger. 


\section{Bon Dadunemard.}

159

fenn wuirben, bafertue ber Rảnferlide Şof tert

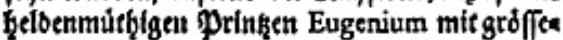
rem গadorud fecumbiret bydtte. Wie nun tit

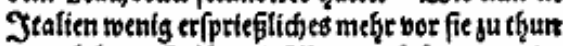

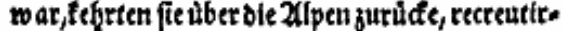
ten thre gefdinddite Eompagnien in Deutfd). lamb, unb marfditrten Anno 1705. unter Dem S5e. neral Harboë nad S) ungarn, wo feltbft fie unter bem Eommanbo des allba commantirender Rdy ferl. Senerals Comte de Herbeville etlidje mafil mit Den rebellen jum fandogemenge gea rathen, uno beg oer jüngften בattion in Sicbere birgen iffre Bravoure rebltá) gewote $[\mathrm{en}$.

Ditemigen Ddnifden Zrouppen, fo in Dent

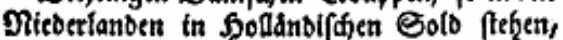

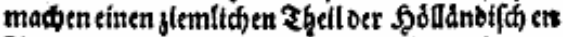
Zrmee aus, und twerben von S. Dut. Durd. Ocm fjerz̧og Carl, von 2 Búrtenberg comnantoiret. Ete marfdjitten Anno 1704. unter demfetbigent

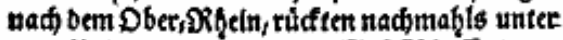
bem Prinşen Eugenio, in Befeufdaff beter Preuffen nad Sodrwaben, und ftunben ineift auf Dem red)ten fflúgel ber Zrmee, als Das ftharffe Zeffen ben J̧ddiftdot bor fid grenge, in weldem fie Das Jhrige reolth thaten, und getwiés nidje twentg juterlangten $\mathfrak{B}$ ictorie contribuirter. 习erwidenes Jaf̧r hqaben fie bey Eroberung ber Brabantifdeen Sinien fid befunben; Geuer aber

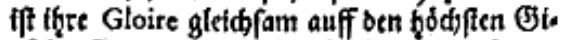
pfel geftiegen, inbem thre Snfanteric auf bem rectren flligel unter dem Duc de Marlborough, ble Eavallerie aber auf bem linden flüget unter

(L) $4 \quad \mathrm{bem}$

Fama V I59f:

Diejenigen Dänischen Trouppen, so in den Niederlanden in Holländischen Sold stehen, machen einen ziemlichen Theil der Holländischen Armee aus, und werden von Sr. Durchl. dem Hertzog Carl von Würtenberg commandiret. Sie marschirten Anno 1704, unter demselbigen nach dem Ober-Rhein, rückten nachmahls unter dem Printzen Eugenio, in Gesellschafft derer Preussen nach Schwaben, und stunden meist auf dem rechten Flügel der Armee, als das scharffe Treffen bey Höchstädt vor sich gienge, in welchem sie das Ihrige redlich thaten, und gewiss nicht wenig zur erlangten Victorie contribuirten. Verwi-
$7_{14}$

Dm Danntmaxd.

Den Senfertige Generals Comte d Herbevil ks Commande haver ladet fec Deris fore Tappetbed mod oe Malcontenter, beign oerlig uOi Den Aflios uDi Giebenburgen.

De Danfle ₹ropper/ fom faat uns Dee Sans Surdy. SDettugens' af $28 \%$ tenberg Commando uoi $\Re$ etocrianbene 1 gior en frop. Deel afoen Sootlanofte Armk. De marcbirede Anno 1704 under famme Gen:ral, til Dbetsolbinen, rutxe fioen urte Der Yyrink Eugenio til Suaben I og frobe melt paa ocn beyre fley. Slagblev boloet ved Sodis Stact bost udi of fiftede jum fover / og contribuerede veo Deris Tappetbeo ide libet tilfamme Viglorie. Uoi bet शlat 1705 fignaliferede oe fig ide minote ubi ben Szabandle finies crobring.

Rene Anno 1706 fige beris Reputse rion ligerom paa ben bonefie fpider i Det Deris Infanteric pao ten boyre Flon uns bee bertugen af Marlborougs, mens Caval. leriet paa oen venftec unber Felt-Marcball Outerkerk veb Derif inromparable Kappets bed $/$ gootmed of fietede mod de franfle Siongel.

Intr. 1714 :

De Danske Tropper, som staar under Hans Durchl. Hertugens af Wyrtenberg Commando udi Nederlandene, giør en stor Deel af den Hollandske Armée. De marcherede Anno 1704 under samme General, til Ober-Rhinen, rykte siden under Printz Eugenio til Svaben, og stode mest paa den høyre Fløy, da det store Slag blev holdet ved Hoch-Stædt, hvorudi de fiktede som Løver, og contribuerede ved deris Tapperhed icke lidet til samme Victorie. Udi det Aar 1705 signaliserede de sig icke mindre udi den Brabandske Linies erobring.

Mens Anno 1706 steg deris Reputation ligesom paa den høyeste spidse, $\mathrm{i}$ det 